ISSN 1678-3921

Journal homepage: www.embrapa.br/pab

For manuscript submission and journal contents, access: www.scielo.br/pab

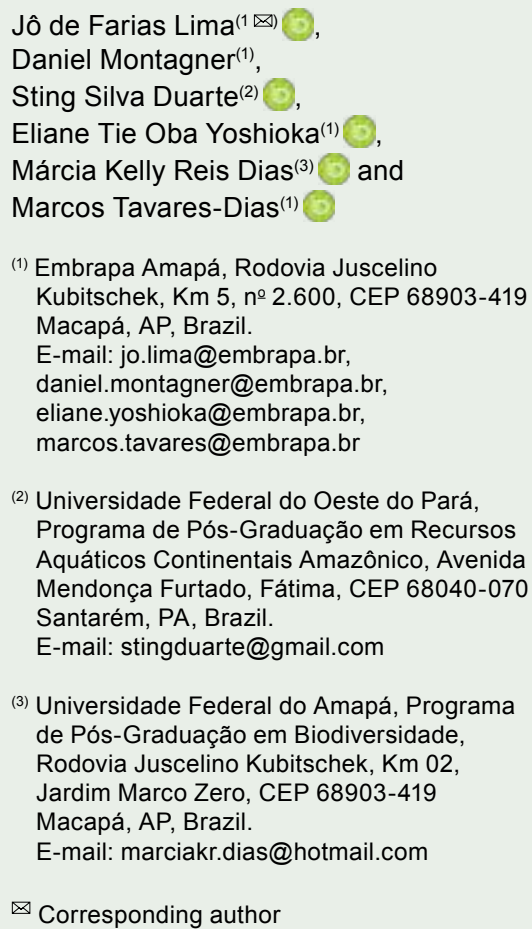

\section{Recirculating system using biological aerated filters on tambaqui fingerling farming}

\begin{abstract}
The objective of this work was to evaluate a recirculating aquaculture system using biological aerated filters in tanks for tambaqui (Colossoma macropomum) fingerlings farming, with two initial stocking densities (1.4 and $2.5 \mathrm{~kg} \mathrm{~m}^{-3}$ ). The biofilters had similar materials (media) and the same granulometric standards, but inverted orders of the media (classic and inverted). The following were monitored for 90 days: water quality; zootechnical, parasitological, and hematological parameters; and hematimetric indices. Water temperature, oxygen levels, $\mathrm{pH}$, electrical conductivity, and dissolved solids concentration were compatible with tambaqui farming and did not differ between the different biofilters and densities. The ammonia and nitrite value was associated with the stocking densities and not with biofilter. The zootechnical and hematological parameters and the hematimetric indices evaluated were not influenced either by the type of biofilter or by the stocking densities. Ichthyophthirius multifiliis, Anacanthorus spathulatus, Notozothecium janauachensis, and Mymarothecium boegeri were the parasites found. The aerated, classical, and inverted biological filters have similar efficiency in maintaining water quality parameters for tambaqui fingerling farming.
\end{abstract}

Index terms: Colossoma macropomum, aquaculture, parasites, production.

\section{Sistema de recirculação usando filtros biológicos aerados no cultivo de alevinos de tambaqui}

Resumo - O objetivo deste trabalho foi avaliar um sistema de recirculação de água com uso de filtros biológicos aerados em tanques de criação de alevinos de tambaqui (Colossoma macropomum), com duas densidades de estocagem (1,4 e 2,5 $\left.\mathrm{kg} \mathrm{m}^{-3}\right)$. Os biofiltros possuíam materiais semelhantes (meios) e os mesmos padrões granulométricos, mas com a ordem dos meios invertida (clássico e invertido). Foram monitorados durante 90 dias: a qualidade da água; os parâmetros zootécnicos, parasitológicos e hematológicos; e os índices hematimétricos. A temperatura da água, os níveis de oxigênio, o $\mathrm{pH}$, a condutividade elétrica e a concentração de sólidos dissolvidos foram compatíveis com a produção de tambaqui e não diferiram entre os diferentes biofiltros e densidades. $\mathrm{O}$ valor de amônia e nitrito foi associado à densidade de estocagem e não ao biofiltro. Os parâmetros zootécnicos e hematológicos e os índices hematimétricos avaliados não foram influenciados nem pelo tipo de biofiltro nem pela densidade de estocagem. Ichthyophthirius multifiliis, Anacanthorus spathulatus, Notozothecium janauachensis e Mymarothecium boegeri foram os parasitas encontrados. Os filtros biológicos aerados, clássico e invertido têm similar eficiência na manutenção de parâmetros de qualidade de água para o cultivo de alevinos de tambaqui.

Termos para indexação: Colossoma macropomum, aquicultura, parasitos, produção. 


\section{Introduction}

The tambaqui (Colossoma macropomum Cuvier 1818) is a native fish species from the Amazon River basin. It is farmed in the northern and northeastern regions of Brazil due to its rapid growth, relative resistance to illnesses and good tolerance to high temperatures and moderate levels of dissolved oxygen in the water (Baldisserotto \& Gomes, 2010). However, tambaqui is cultured with low technological levels in most of Brazil, occurring on extensive and semiintensive systems in earthen ponds. In 2014, the production reached 139,209 tons, which was more than 57\% higher than in 2013 (IBGE, 2017).

The pisciculture sector has invested in technologies aimed at improving tambaqui production and has gradually led many farmers to shift tambaqui culture from traditional semi-intensive systems to more intensive production systems (Silva \& Fujimoto, 2015). Expanding semi-intensive and intensive system for this fish will lead to increasing volumes of waste nitrogen and solids that foul the water, making it necessary to generate new technologies that can control and reduce effluent pollution to near zero, as observed in recirculation aquaculture systems (RAS).

The RAS can be defined as systems where the outlet water from fish tanks is treated and re-used instead of being released into a recipient water body (Lekang, 2013). Different water treatment technologies may be appropriate to maintain water quality parameters within acceptable levels in this system. Among the common practices, the conversion of nitrogenous wastes with biofilters (Lekang, 2013) is included. The biofilters containing substrates of different materials (media) were designed to have maximum contact surface in order to promote the growth of the bacterial community through the production of biofilms (Avnimelech, 2006).

Most of the biofiltration on recirculating systems has been focused on integrating aerobic and anaerobic microbial processes for the elimination of waste products of nitrogen in the form of ammonia, excreted by animal respiration and organic matter decomposition, using static bed filters and moving bed bioreactors (Suhr \& Pedersen, 2010). In the static bed filter, the media (mineral or plastic) is fixed and not moving. The water runs through the media as a laminar flow to make contact with the bacterial film. In the moving bed filter, the media (usually plastic) is moving around in the water inside the biofilter by a current created by pumping in the air. Because of the constant movement of the media, moving bed filters can be packed more hardly than fixed bed filters, thus, reaching a higher turnover rate per $\mathrm{m}^{3}$ of the biofilter. There are no significant differences in the turnover rate calculated per $\mathrm{m}^{2}$ (filter surface area) as the efficiency of the bacterial film in either of the two filters systems (Suhr \& Pedersen, 2010). However, periodic backwashing is necessary to avoid blocking of the system with fixed bed filters due to solids entrapment and biofilm growth (Suhr \& Pedersen, 2010).

In Brazil, few companies are specializing in the production of media for biofilter, and the models currently available on the market are imported, a fact that ends up raising the costs, making it unfeasible to install RAS for small farmers, especially the ones that use modern technologies as moving bed biofilters. Thus, the question that arises is whether the variations in the conventional biological filtration system using static bed biofilters and different stocking density would influence the tambaqui performance in a simplified RAS.

Associated to parasitology, the establishing of hematological values should be adopted as a reference to evaluate fish health status (Tavares-Dias, 2015), because this tool provides a reliable evaluation via non-lethal means (Satheeshkumar et al., 2012). The blood parameters of fish are closely related to their metabolism, nutritional status, and diseases. They can usually be used to evaluate the physiological condition of the fish population and assess the stress caused by the environment and parasites (Ranzani-Paiva et al., 2013; Li et al., 2014; Pinheiro et al., 2015; Soares et al., 2016). Despite its importance, there are few references regarding tambaqui health status, which is farmed in RAS, evaluating such parameters.

The objective of this work was to evaluate a recirculating aquaculture system using biological aerated filters in tanks for tambaqui fingerlings farming, with 1.4 and $2.5 \mathrm{~kg} \mathrm{~m}^{-3}$ initial stocking densities.

\section{Material and Methods}

The trial occurred in the laboratory of the center for agroforestry research of Embrapa Amapá (Embrapa - Brazilian Agricultural Research Corporation - unit 
located in state of Amapá, Brazil). The experiment was conducted in a $2 \times 2$ factorial design with the factors type of biofilters (B1 - conventional and B2 inverted) and two initial fingerlings stocking densities $\left(1.42\right.$ and $\left.2.50 \mathrm{~kg} \mathrm{~m}^{-3}\right)$ with two replications each. The media of biofilters had similar materials and same granulometric standards but in different orders. Each media comprised $15 \%$ of total volume of the biofilter. Biofilter 1 was composed of sand, minute pebbles, bamboo slices, and ceramic, in this sequence; and Biofilter 2 consisted of ceramic, bamboo slices, minute pebbles and sand, in this order.

Three hundred and twenty fingerlings of tambaqui (160 fingerlings with $35.53 \pm 2.77 \mathrm{~g}$ and 160 fingerlings with $62.71 \pm 2.75 \mathrm{~g}$ ) were farmed for 90 days in RAS using aired fixed bed biofilters, a submerged media wastewater treatment that combined biological and mechanical filtration. The RAS comprised four circular ponds with $500 \mathrm{~L}$ of capacity, a decanter with $50 \mathrm{~L}$ of capacity and fixed bed biofilters with a volume of $500 \mathrm{~L}$ interconnected by complex drain and supply tubes, from which water is transported by an air-lift pump and gravity (Figure 1).

The fish received commercial feed (Aqua-Guabi, Guabi Nutrição e Saúde Animal, state of São Paulo, Brazil) containing the following security levels: moisture (max.) $80 \mathrm{~g} \mathrm{~kg}^{-1}$, crude protein (min.) 360 $\mathrm{g} \mathrm{kg}^{-1}$, ethereal extract (min.) $80 \mathrm{~g} \mathrm{~kg}^{-1}$, gross fiber (max.) $75 \mathrm{~g} \mathrm{~kg}^{-1}$, mineral matter (max.) $115 \mathrm{~g} \mathrm{~kg}^{-1}$, calcium (max.) $23 \mathrm{~g} \mathrm{~kg}^{-1}$, phosphorus (min.) $7 \mathrm{~g} \mathrm{~kg}^{-1}$. The feed was offered three times a day, up to the limit of $3 \%$ of the total fish weight, as suggested by the manufacturer and according to consumption.

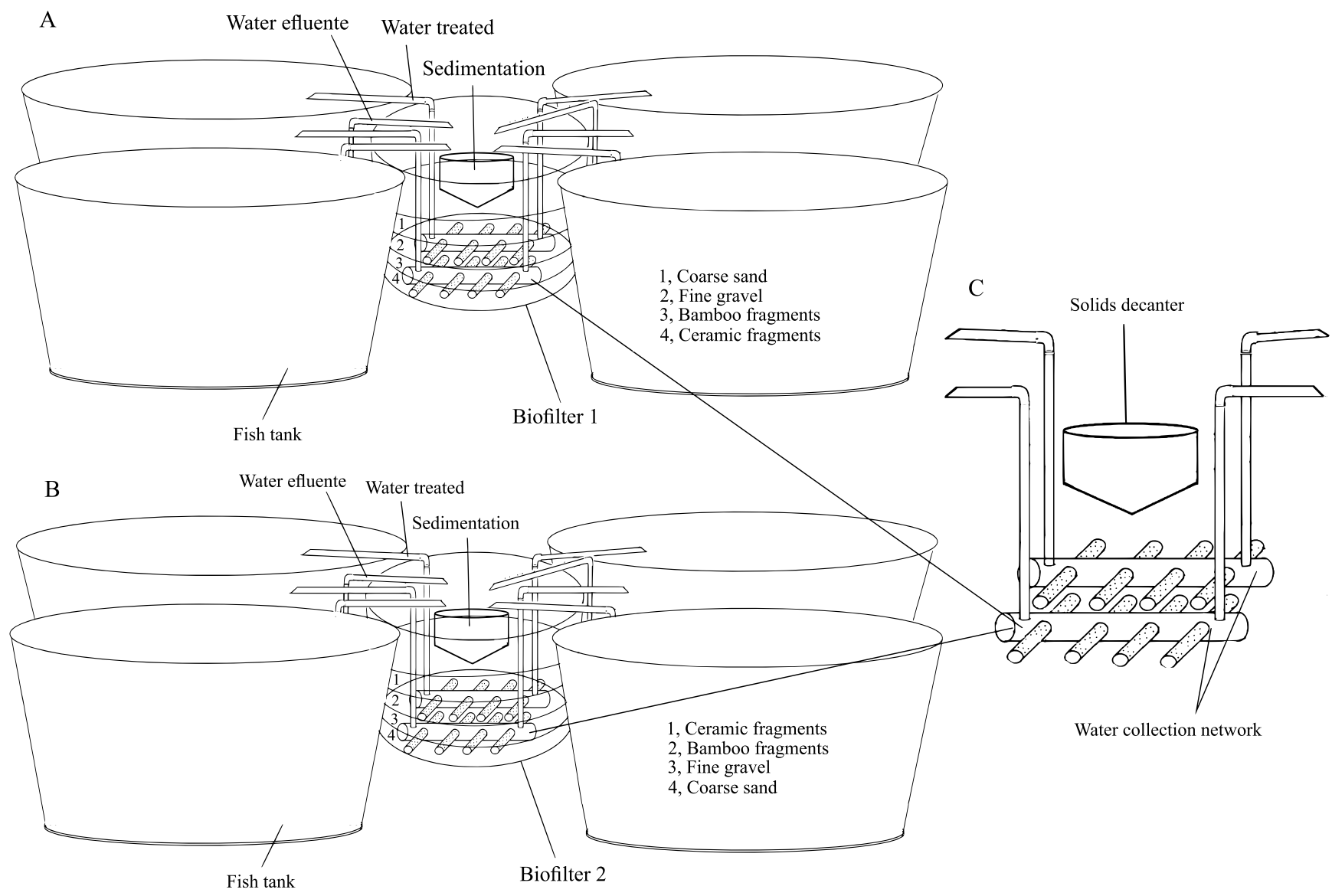

Figure 1. Detail of recirculating aquaculture system used for fingerling farming of tambaqui (Colossoma macropomum). A, biofilter 1 showing the general layout and distribution of each bed fixed. B, biofilter 2 showing the general layout and distribution of each bed fixed. C, detail of water collection network. 
The following water quality parameters were measured daily: $\mathrm{pH}$, water temperature $\left({ }^{\circ} \mathrm{C}\right)$, dissolved oxygen (mg $\left.\mathrm{L}^{-1}\right)$, electrical conductivity (EC $\mu \mathrm{S} \mathrm{cm}^{-1}$ ) and total dissolved solids (TDS $-\mathrm{mg} \mathrm{L}^{-1}$ ) using a multiparameter meter (Horiba U10, Horiba Instruments Brazil, São Paulo, Brazil). Total ammonia nitrogen (TAN $\left.-\mathrm{mg} \mathrm{L}^{-1}\right)$ and nitrite $\left(\mathrm{NO}_{2}{ }^{-}-\mathrm{mg} \mathrm{L}^{-1}\right)$ levels were measured bi-weekly using a Benchtop Multiparameter Photometer for Water Analysis (Hanna Model HI 83208, Hanna Instruments Brasil, Tamboré, Barueri, Brazil) at the water entry and outlet points of the farming tanks. The tanks were populated ten days after the filters had been assembled. The growth of nitrifying bacteria was stimulated through adding ammonium hydroxide $\left(\mathrm{NH}_{4} \mathrm{OH}\right)$ immediately after the biological filters had been assembled. These were additionally enriched with a solution containing $30 \mathrm{~g}$ of regular sugar every three days during the first month of farming. The $\mathrm{pH}$ level was controlled by adding 15 $\mathrm{g}$ of dolomitic lime in the tanks containing different biofilters, every seven days. Water flow between biofilter and fish tanks was adjusted at $1.5 \mathrm{~L}$ per minute. No water discharge or displacement occurred during the trial period, except when replacing the water lost through evaporation, siphoning the floor of the culture tanks, and cleaning the floor of the decanters. Only $10 \%$ of the water of system was replaced in each operation twice a week.

At the beginning and end of the experiment, the zootechnical parameters were measured. All fish were weighed $(\mathrm{g})$ in a digital scale and measured in total length $(\mathrm{cm})$ using a caliper to determine the weight gain (WG), individual mean consumption (IMC), individual mean consumption of feed at the end of the experiment (IMCE), apparent feed conversion ratio (AFC), specific growth rate (SGR), fish survival rate (SR) according to Pereira Junior et al. (2013) and Pinheiro et al. (2015), and relative condition factor (Kn), as described by Le Cren (1951).

After 90 days of farming, the blood of five fish was collected by replicate of each biofilter, and the density of the caudal vessel was collected using syringes containing sodium heparin, for hematological parameters analysis. The samples were preserved on wet ice around $4^{\circ} \mathrm{C}$ during the analysis. Hematocrit was assessed through the microhematocrit method; hemoglobin concentration was evaluated using the cyanmethaemoglobin method; and total red blood cells were counted in a Neubauer chamber (Ranzani-Paiva et al., 2013). These data were used to calculate Wintrobe's hematimetric indices: mean corpuscular volume (MCV) and mean corpuscular hemoglobin concentration (MCHC). The differential leukocytes count was performed on blood smears that were stained with a combination of May-Grünwald-Giemsa-Wright. The total thrombocytes and leukocytes count was determined through indirect method (Ranzani-Paiva et al., 2013).

After the blood collection, each fish was necropsied for parasitological analysis of mouth, opercula, and gills, which were examined for the collection of ectoparasites. The gastrointestinal tract was studied to collect endoparasites. The collection, fixation, conservation, counting and staining of parasites for identification followed previous recommendations (Tavares-Dias, 2015). The prevalence and mean abundance were accessed according to Tavares-Dias (2015).

The data initially assumed a normal distribution and homoscedasticity using the Shapiro-Wilk and Bartlett tests, respectively. Data were subjected to two-way analysis of variance (biofilter versus fish stocking density), followed by the Student-Newman-Keuls test, at $5 \%$ probability, for comparison between treatments, except for parasites prevalence. For comparison of parasitic prevalence, data were analyzed using the $\chi^{2}$ test, at $5 \%$ probability (Zar, 2010).

\section{Results and Discussion}

Water temperature, oxygen levels, $\mathrm{pH}$, electrical conductivity, total dissolved solids and total ammonia concentration in the RAS of the tambaqui fingerlings did not differ between treatments (Table 1). The water quality parameters were similar to that recommended for farming Amazonian fish on traditional fish farming (Oliveira et al., 2007; Chagas et al., 2007; Pereira Júnior et al., 2013). The results show that both biological filters used were equally efficient, particularly on controlling the ammonia, nitrite, and total dissolved solid levels. The amount of ammonia excreted by tambaqui is directly related to its mass and inversely related to temperature (Ismiño-Orbe et al., 2003). Therefore, variations observed at ammonia and nitrite values in the present study are associated with 
the difference between fish weights, given that the temperature was relatively similar in the treatments.

About the zootechnical parameters, the survival rate of the fish was $100 \%$ at both farming densities. Moreover, the feed consumption and weight gain among the fingerlings were similar with the two types of biofilters (Table 2). The quality of the fish-farming environment needs to be sufficient to ensure optimum conditions for growth of the fish species, considering that when conditions are inadequate, fish growth and health are diminished. The growth parameters obtained here for tambaqui were not influenced either by the type of biofilter or by the stocking densities. The weight gain, mean feed consumption, apparent feed conversion rate, specific growth rate, and fish survival rate recorded in this work were compatible to those reported for tambaqui farmed in ponds without water renovation (Oliveira et al., 2007; Pereira-Júnior et al., 2013; Pinheiro et al., 2015), in ponds with continuous water renovation (Sipaúba-Tavares et al., 2003) and in net-cages (Chagas et al., 2007; Silva \& Fujimoto, 2015). Therefore, according to these results, both types of filters tested here have functioned satisfactorily in production of tambaqui fingerlings.

The hematocrit, hemoglobin, $\mathrm{MCV}$, and $\mathrm{MCHC}$ levels and the erythrocyte, thrombocyte, and neutrophil counts were similar among the fingerlings at the two stocking densities and with both biofilters (Table 3). However, the total leukocyte and lymphocyte counts were greater among the fish farmed in the RAS using biofilter 2, regardless of fish stocking density $\left(1.4 \mathrm{~kg} \mathrm{~m}^{-3}\right.$ and $2.5 \mathrm{~kg} \mathrm{~m}^{-3}$ of fish), while PAS-Positive granular leukocytes (PAS-GL) count was only greater among fish farmed at the highest density using biofilter 2 . The monocytes count was lower among fish farmed in the RAS using biofilter 2 with the lower stocking density. The eosinophils count in fingerlings was greater in the RAS using biofilter 2 with the higher density and in the RAS with biofilter 1 at the lower density.

Inadequate environmental conditions in RAS may cause stress to the fish and negatively affect blood parameters ( $\mathrm{Li}$ et al., 2014), but this was not observed in this study. The hematocrit, hemoglobin, MCV and MCHC levels, erythrocytes, thrombocytes,

Table 1. Water quality parameters in a recirculating aquaculture system using two biological filters (B1 - classical and B2 - inverted) and two stocking densities (D1 - 2.5 $\mathrm{kg} \mathrm{m}^{-3}$ and D2 - $1.4 \mathrm{~kg} \mathrm{~m}^{-3}$ ) of tambaqui (Colossoma macropomum) farmed during 90 days.

\begin{tabular}{lccccccc}
\hline Treatments & Temperature $\left({ }^{\circ} \mathrm{C}\right)$ & $\mathrm{pH}$ & $\mathrm{EC}\left(\mu \mathrm{S} \mathrm{cm}{ }^{-1}\right)$ & $\mathrm{DO}\left(\mathrm{mg} \mathrm{L}^{-1}\right)$ & $\mathrm{TDS}\left(\mathrm{mg} \mathrm{L}^{-1}\right)$ & $\mathrm{TAN}_{\left(\mathrm{mg} \mathrm{L}^{-1}\right)} \mathrm{NO}_{2}^{-}\left(\mathrm{mg} \mathrm{L}^{-1}\right)$ \\
\hline $\mathrm{B} 1 / \mathrm{D} 1$ & $27.7 \pm 0.5$ & $6.1 \pm 0.5$ & $110.6 \pm 0.3$ & $6.3 \pm 0.4$ & $0.07 \pm 0.02$ & $1.9 \pm 0.6$ & $0.27 \pm 0.3$ \\
$\mathrm{~B} 1 / \mathrm{D} 2$ & $27.8 \pm 0.6$ & $6.2 \pm 0.6$ & $102.7 \pm 0.3$ & $6.2 \pm 0.4$ & $0.07 \pm 0.02$ & $1.3 \pm 0.3$ & $0.25 \pm 0.4$ \\
$\mathrm{~B} 2 / \mathrm{D} 1$ & $27.9 \pm 0.5$ & $6.1 \pm 0.6$ & $98.3 \pm 0.3$ & $6.4 \pm 0.5$ & $0.06 \pm 0.02$ & $2.2 \pm 0.4$ & $0.29 \pm 0.3$ \\
$\mathrm{~B} 2 / \mathrm{D} 2$ & $27.7 \pm 0.6$ & $6.2 \pm 0.6$ & $110.5 \pm 0.3$ & $6.1 \pm 0.6$ & $0.07 \pm 0.02$ & $1.9 \pm 0.3$ & $0.26 \pm 0.2$ \\
\hline
\end{tabular}

EC, electrical conductivity; DO, dissolved oxygen; TDS, total dissolved solid; TAN, total ammonia nitrogen; $\mathrm{NO}_{2 .}$, nitrite. Values express mean \pm standard deviation.

Table 2. Zootechnical parameters of tambaqui (Colossoma macropomum) farmed during 90 days in a recirculating aquaculture system using two biological filters (B1 - classical and B2 - inverted) and two stocking densities (D1 - 2.5 kg m and D2 - 1.4 $\left.\mathrm{kg} \mathrm{m}^{-3}\right)$.

\begin{tabular}{lcccc}
\hline Zootecnical parameters & B1/D1 & B1/D2 & B2/D1 & B2/D2 \\
\hline Initial weight (g) & $63.1 \pm 3.4$ & $37.2 \pm 0.4$ & $61.4 \pm 1.6$ & $36.7 \pm 0.9$ \\
Final weight (g) & $168.8 \pm 0.4$ & $133.1 \pm 10.6$ & $161.43 \pm 9.2$ & $136.4 \pm 9.5$ \\
Initial length (cm) & $12.5 \pm 0.4$ & $10.4 \pm 0.4$ & $12.6 \pm 0.2$ & $17.2 \pm 0.2$ \\
Final length (cm) & $17.3 \pm 0.2$ & $16.5 \pm 0.5$ & $100.1 \pm 10.4$ & $16.5 \pm 0.4$ \\
Weight gain (g) & $105.7 \pm 9.9$ & $95.9 \pm 10.7$ & $2.14 \pm 0.07$ & $99.7 \pm 10.4$ \\
Consumption of feed (g) & $2.31 \pm 0.11$ & $1.61 \pm 0.06$ & 100 & $1.61 \pm 0.01$ \\
Survival (\%) & 100 & 100 & $1.94 \pm .19$ & 100 \\
Apparent feed conversion rate & $1.96 \pm 0.21$ & $1.52 \pm 0.12$ & $1.07 \pm 0.08$ & $1.46 \pm 0.17$ \\
Specific growth rate (\%) & $1.09 \pm 0.07$ & $1.41 \pm 0.09$ & $1.00 \pm 0.02$ & $1.45 \pm 0.10$ \\
Relative condition factor & $1.00 \pm 0.01$ & $1.00 \pm 0.01$ & & $1.00 \pm 0.01$ \\
\hline
\end{tabular}

Values express mean \pm standard deviation. 
monocytes, eosinophils, PAS-GL, and neutrophils counts for fingerlings of tambaqui in the present study are considered to be within the reference values for the same species farmed in earth ponds (Tavares-Dias, 2015), indicating that the recirculation system using fixed bed biological filters had good environmental conditions for the cultivation of tambaqui fingerlings. Other parameters as total leukocytes count for tambaqui showed variations that were influenced by the lymphocytes, monocytes, PAS-GL and eosinophils count, due to the numerous functions of these cells in immunological system (Ranzani-Paiva et al., 2013; Pinheiro et al., 2015) that probably were affected by the parasite load observed in the present study. Lymphocytes are involved in the production of immunoglobulins and defense modulation. Monocytes and PAS-GL are phagocytes that migrate to inflammatory foci during infectious processes, while eosinophils participate in the defense process against parasites (Ranzani-Paiva et al., 2013; Pinheiro et al., 2015).

Only ectoparasites including Ichthyophthirius multifiliis (Protozoa), Anacanthorus spathulatus, Notozothecium janauachensis, and Mymarothecium boegeri (Monogenoidea) were found in tambaqui of this study (Table 4). The exception is $N$. janauachensis, for which the prevalence of parasites among the fingerlings was similar in both biofilters, as well as the density of biomass stocking. However, stocking density influenced the abundance of $A$. spathulatus, $M$. boegeri, and $N$. janauachensis, which was greater at the initial density ( $2.50 \mathrm{~kg} \mathrm{~m}^{-3}$ of fish), farmed in the RAS using biofilter 1 . The protozoan I. multifiliis was more abundant among fingerlings, with higher stocking density $\left(2.5 \mathrm{~kg} \mathrm{~m}^{-3}\right.$ of fish), farmed using biofilter 2 (Table 4). Apparently, stocking density in tambaqui affected parasitic intensity, but it has not affected parasite prevalence. Since a significant difference was not observed between parasitic abundance and prevalence of $A$. spathulatus, $M$. boegeri, and $N$. janauachensis in both biofilters, it is acceptable to infer that the media used as bed, fixed in each biofilter, was not a decisive factor on the abundance and prevalence of these parasites.

The abundance and prevalence of I. multifiliis, A. spathulatus, $N$. janauachensis, and M. boegeri reported in this study was lower than that reported for tambaqui by Pinheiro et al. (2015) and Soares et al. (2016), indicating that the parasitic load of this fish farmed in RAS was lower in comparison with the traditional system, regardless of the type of biofilter used here.

Table 3. Hematimetric indices of tambaqui (Colossoma macropomum) farmed during 90 days in a recirculating aquaculture system using two biological filters (B1 - classical, and B2 - inverted) and two stocking densities (D1 - $2.5 \mathrm{~kg} \mathrm{~m}^{-3}$, and D2 - 1.4 $\left.\mathrm{kg} \mathrm{m}^{-3}\right)^{(1)}$.

\begin{tabular}{|c|c|c|c|c|}
\hline Hematimetric indices & $\mathrm{B} 1 / \mathrm{D} 1$ & $\mathrm{~B} 1 / \mathrm{D} 2$ & $\mathrm{~B} 2 / \mathrm{D} 1$ & $\mathrm{~B} 2 / \mathrm{D} 2$ \\
\hline Red blood cells $\left(\times 10^{6} \mu \mathrm{L}^{-1}\right)$ & $1.68 \pm 0.38 \mathrm{aA}$ & $1.72 \pm 0.22 \mathrm{aA}$ & $1.66 \pm 0.30 \mathrm{aA}$ & $1.73 \pm 0.26 \mathrm{aA}$ \\
\hline Hematocrit (\%) & $19.5 \pm 2.6 \mathrm{aA}$ & $18.8 \pm 2.5 \mathrm{aA}$ & $17.9 \pm 1.8 \mathrm{aA}$ & $19.3 \pm 2.4 \mathrm{aA}$ \\
\hline Hemoglobin $\left(\mathrm{g} \mathrm{dL}^{-1}\right)$ & $9.7 \pm 1.7 \mathrm{aA}$ & $9.2 \pm 1.1 \mathrm{aA}$ & $9.6 \pm 0.9 \mathrm{aA}$ & $9.63 \pm 1.6 \mathrm{aA}$ \\
\hline $\operatorname{MCV}\left(\mathrm{fL}^{-1}\right)$ & $120.6 \pm 23.7 \mathrm{aA}$ & $110.6 \pm 21.0 \mathrm{aA}$ & $111.6 \pm 23.0 \mathrm{aA}$ & $114.2 \pm 14.9 \mathrm{aA}$ \\
\hline $\mathrm{MCHC}\left(\mathrm{g} \mathrm{dL}^{-1}\right)$ & $50.0 \pm 6.3 \mathrm{aA}$ & $50.7 \pm 6.9 \mathrm{aA}$ & $53.5 \pm 5.7 \mathrm{aA}$ & $50.1 \pm 7.6 \mathrm{aA}$ \\
\hline Thrombocytes $\left(\mu \mathrm{L}^{-1}\right)$ & $110.8 \pm 41.8 \mathrm{aA}$ & $90.8 \pm 38.6 \mathrm{aA}$ & $112.6 \pm 43.9 \mathrm{aA}$ & $114.3 \pm 38.5 \mathrm{aA}$ \\
\hline Leukocytes $\left(\times 10^{3} \mu \mathrm{L}^{-1}\right)$ & $74.9 \pm 24.8 \mathrm{aA}$ & $84.8 \pm 12.8 \mathrm{aA}$ & $82.6 \pm 22.3 \mathrm{bA}$ & $94.2 \pm 18.3 \mathrm{bA}$ \\
\hline Lymphocytes $\left(\times 10^{3} \mu \mathrm{L}^{-1}\right)$ & $65.4 \pm 23.2 \mathrm{aA}$ & $76.2 \pm 11.2 \mathrm{aA}$ & $70.4 \pm 16.3 \mathrm{bA}$ & $84.9 \pm 15.6 \mathrm{aA}$ \\
\hline Monocytes $\left(\times 10^{3} \mu \mathrm{L}^{-1}\right)$ & $3.7 \pm 2.4 \mathrm{aA}$ & $3.5 \pm 1.3 \mathrm{aA}$ & $3.6 \pm 3.2 \mathrm{aA}$ & $3.0 \pm 1.4 \mathrm{aA}$ \\
\hline Neutrophils $\left(\times 10^{3} \mu \mathrm{L}^{-1}\right)$ & $4.6 \pm 3.7 \mathrm{aA}$ & $3.1 \pm 2.8 \mathrm{aA}$ & $5.9 \pm 5.1 \mathrm{aA}$ & $4.8 \pm 4.4 \mathrm{aA}$ \\
\hline PAS-GL $\left(\times 10^{3} \mu \mathrm{L}^{-1}\right)$ & $1.2 \pm 0.8 \mathrm{aA}$ & $1.3 \pm 0.3 \mathrm{aA}$ & $1.3 \pm 0.4 \mathrm{aA}$ & $1.4 \pm 0.4 \mathrm{aA}$ \\
\hline Eosinophils $\left(\times 10^{3} \mu \mathrm{L}^{-1}\right)$ & $1.8 \pm 0.1 \mathrm{aA}$ & $3.8 \pm 0.1 \mathrm{aB}$ & $1.9 \pm 0.1 \mathrm{aA}$ & $2.9 \pm 0.1 \mathrm{aB}$ \\
\hline
\end{tabular}

${ }^{(1)}$ Means followed by equal letters, lowercase between types of filters and uppercase between densities, do not differ by the Student-Newman-Keuls test, at $5 \%$ probability. Values express mean \pm standard deviation. $\mathrm{MCV}$, mean corpuscular volume. MCHC, mean corpuscular hemoglobin concentration. PAS-GL, positive granular leukocytes. 
Table 4. Prevalence and mean abundance of parasites in gills of tambaqui (Colossoma macropomum) farmed during 90 days in a recirculating aquaculture system using two biological filters (B1 - classical, and B2 - inverted) and two stocking densities (D1 $-2.5 \mathrm{~kg} \mathrm{~m}^{-3}$, and D2 $\left.-1.4 \mathrm{~kg} \mathrm{~m}^{-3}\right)^{(1)}$.

\begin{tabular}{|c|c|c|c|c|c|}
\hline Parasites & & $\mathrm{B} 1 / \mathrm{D} 1$ & $\mathrm{~B} 1 / \mathrm{D} 2$ & $\mathrm{~B} 2 / \mathrm{D} 1$ & $\mathrm{~B} 2 / \mathrm{D} 2$ \\
\hline \multirow{2}{*}{ I. multifiliis } & Prevalence (\%) & $75.0 \mathrm{aA}$ & $75.0 \mathrm{aA}$ & $100 \mathrm{bB}$ & $100 \mathrm{bB}$ \\
\hline & Mean abundance & $2,700.0 \pm 2,156.8 \mathrm{aA}$ & $3,001.9 \pm 2,666.0 \mathrm{aA}$ & $5,070.6 \pm 2,286.3 \mathrm{bA}$ & $1,867.6 \pm 941.9 \mathrm{aB}$ \\
\hline \multirow{2}{*}{ A. spatulathus } & Prevalence (\%) & $100.0 \mathrm{aA}$ & $81.2 \mathrm{bB}$ & $75.0 \mathrm{bB}$ & $87.5 \mathrm{bB}$ \\
\hline & Mean abundance & $23.2 \pm 18.2 \mathrm{aA}$ & $6.2 \pm 9.6 \mathrm{aB}$ & $11.1 \pm 13.4 \mathrm{aB}$ & $8.8 \pm 6.4 \mathrm{aB}$ \\
\hline \multirow{2}{*}{ M. boegeri } & Prevalence (\%) & $31.2 \mathrm{aA}$ & $16.3 \mathrm{bB}$ & $25.0 \mathrm{aA}$ & $18.7 \mathrm{bB}$ \\
\hline & Mean abundance & $4.4 \pm 7.3 \mathrm{aA}$ & $0.2 \pm 0.8 \mathrm{bB}$ & $0.6 \pm 1.0 \mathrm{bB}$ & $0.4 \pm 0.8 \mathrm{bB}$ \\
\hline \multirow{2}{*}{ N. janauachensis } & Prevalence (\%) & $25.0 \mathrm{aA}$ & $0.0 \mathrm{bB}$ & $0.0 \mathrm{bB}$ & $0.0 \mathrm{bB}$ \\
\hline & Mean abundance & $1.1 \pm 2.5 \mathrm{aA}$ & $0.0 \mathrm{bB}$ & $0.0 \mathrm{bB}$ & $0.0 \mathrm{bB}$ \\
\hline
\end{tabular}

${ }^{(1)}$ Means followed by equal letters, lowercase between types of filters and uppercase between densities, do not differ by the Student-Newman-Keuls test, at $5 \%$ probability.

\section{Conclusions}

1. The biological aerated filters, classical and inverted, have similar efficiency in maintaining water quality for tambaqui (Colossoma macropomum) fingerling farming.

2. The growth parameters and survival of tambaqui are not influenced either by the type of biofilter or by the stocking densities.

3. The stocking density influences the parasitic load of tambaqui in both aerated filters, classical and inverted, with higher incidence of parasites in the stocking density of $2.5 \mathrm{~kg} \mathrm{~m}^{-3}$.

\section{Acknowledgments}

To the Conselho Nacional de Desenvolvimento Científico e Tecnológico $(\mathrm{CNPq}$ process No. 444367/2014-4) for financial support through a research productivity grant for Dr. Marcos Tavares Dias (CNPq process No. 303013/2015-0).

\section{References}

AVNIMELECH, Y. Bio-filters: the need for an new comprehensive approach. Aquacultural Engineering, v.34, p. 172-178, 2006. DOI: 10.1016/j.aquaeng.2005.04.001.

BALDISSEROTTO, B.; GOMES, L. de C. (Org.). Espécies nativas para piscicultura no Brasil. 2.ed. rev. e ampl. Santa Maria: Ed. da UFSM, 2010. 606p.

CHAGAS, E.C.; GOMES, L. de C.; MARTINS JÚNIOR, H.; $\mathrm{ROUBACH}, \mathrm{R}$. Produtividade de tambaqui criado em tanquerede com diferentes taxas de alimentação. Ciência Rural, v.37, p.1109-1115, 2007. DOI: https://doi.org/10.1590/S010384782007000400031 .

IBGE. Instituto Brasileiro de Geografia e Estatística. Sistema IBGE de Recuperação Automática - SIDRA. Pesquisa da Pecuária Municipal: Tabela 3940: Produção da aquicultura, por tipo de produto. Available at: $<$ http://www.sidra.ibge.gov.br/ bda/tabela/listabl.asp?c $=3940 \& z=t \& o=21>$. Accessed on: Nov. 2 2017.

ISMIÑO-ORBE, R.A.; ARAUJO-LIMA, C.A.R.M.; GOMES, L. de C. Excreção de amônia por tambaqui (Colossoma macropomum) de acordo com variações na temperatura da água e massa do peixe. Pesquisa Agropecuária Brasileira, v.38, p.1243-1247, 2003. DOI: https://doi.org/10.1590/S0100204X2003001000015.

LE CREN, E.D. The length-weight relationship and seasonal cycle in gonadal weight and condition in the perch (Perca fluviatilis). Journal of Animal Ecology, v.20, p.201-219, 1951. DOI: https://doi.org/10.2307/1540.

LEKANG, O.-I. Aquaculture Engineering. $2^{\text {nd }}$ ed. Chichester: Wiley-Blackwell, 2013. 432p.

LI, X.; BLANCHETON, J.-P.; LIU, Y.; TRIPLET, S.; MICHAUD, L. Effect of oxidation - reduction potential on performance of European sea bass (Dicentrarchus labrax) in recirculation aquaculture systems. Aquaculture International, v.22, p.12631282, 2014. DOI: https://doi.org/10.1007/s10499 01397453.

OLIVEIRA, R.P. de C.; SILVA, P.C.; PÁDUA, D.M.C.; AGUIAR, M.; MAEDA, H.; MACHADO, N.P.; RODRIGUES, V.; SILVA, R.H. da. Efeitos da densidade de estocagem sobre a qualidade da água na criação do tambaqui (Colossoma macropomum, Cuvier, 1818) durante a segunda alevinagem, em tanques fertilizados. Ciência Animal Brasileira, v.8, p.705-711, 2007.

PEREIRA JUNIOR, G.P.; PEREIRA, E.M. de O.; PEREIRA FILHO, M.; BARBOSA, P. de S.; SHIMODA, E.; BRANDÃO, L.V. Desempenho produtivo de juvenis de tambaqui (Colossoma macropomum Cuvier, 1818) alimentados com rações contendo farinha de crueira de mandioca (Manihot esculenta, Crantz) em 
substituição ao milho (Zea mays). Acta Amazonica, v.43, p.217226, 2013.

PINHEIRO, D.A.; CAVERO, B.A.S.; VARGAS, L.; BRACCINI, G.L.; YOSHIOKA, E.T.O.; OLIVEIRA, M.S.B.; TAVARESDIAS, M. Performance, parasitic infections, hematology and hepatic histology of Colossoma macropomum (tambaqui) fed on homeopathic product. African Journal of Pharmacy and Pharmacology, v.9, p.82-90, 2015. DOI: https://doi.org/10.5897/ AJPP2014. 4194.

RANZANI-PAIVA, M.J.T.; PÁDUA, S.B. de; TAVARES-DIAS, M.; EGAMI, M.I. Métodos para análise hematológica em peixes. Maringá: Eduem, 2013. 135p.

SATHEESHKUMAR, P.; ANANTHAN, G.; SENTHILKUMAR, D.; KHAN, A.B.; JEEVANANTHAM, K. Comparative investigation on haematological and biochemical studies on wild marine teleost fishes from Vellar estuary, southeast coast of India. Comparative Clinical Pathology, v.21, p.275-281, 2012. DOI: https://doi.org/10.1007/s00580-010-1091-5.

SILVA, C.A. da; FUJIMOTO, R.Y. Crescimento de tambaqui em resposta a densidade de estocagem em tanques-rede. Acta Amazonica, v.45, p.323-333, 2015. DOI: https://doi.org/10.1590/1809-4392201402205.
SIPAÚBA-TAVARES, L.H.; GOMES, J.P.F. dos S.; BRAGA, F.M. de S. Effect of liming management on the water quality in Colossoma macropomum ("tambaqui") ponds. Acta Limnologica Brasiliensia, v.15, p.95-103, 2003.

SOARES, B.V.; NEVES, L.R.; OLIVEIRA, M.S.B.; CHAVES, F.C.M.; DIAS, M.K.R.; CHAGAS, E.C.; TAVARES-DIAS, M. Antiparasitic activity of the essential oil of Lippia alba on ectoparasites of Colossoma macropomum (tambaqui) and its physiological and histopathological effects. Aquaculture, v.452, p.107-114, 2016. DOI: https://doi.org/10.1016/j. aquaculture.2015.10.029.

SUHR, K.I.; PEDERSEN, P.B. Nitrification in moving bed and fixed biofilters treating effluent water from a large commercial outdoor rainbow trout RAS. Aquacultural Engineering, v.42, p.31-37, 2010. DOI: https://doi.org/10.1016/j.aquaeng.2009.10.001.

TAVARES-DIAS, M. Parâmetros sanguíneos de referência para espécies de peixes cultivados. In: TAVARES-DIAS, M.; MARIANO, W. dos S. (Org.). Aquicultura no Brasil: novas perspectivas. São Carlos: Pedro \& João, 2015. p.11-44.

ZAR, J.H. Biostatistical analysis. $5^{\text {th }}$ ed. New Jersey: Prentice Hall, 2010. 944p. 